\title{
Evaluating Performance of University Spin-Off Companies: Lessons from Italy
}

\author{
Barbara Bigliardi', Francesco Galati², and Chiara Verbano³
}

\begin{abstract}
Academic spin-offs are very special start-up companies that are founded by an academic inventor with the aim to exploit technological knowledge that originated within a University setting in order to develop products or services. During the last two decades, academic spin-offs have received increasing attention from both researchers and practitioners, mainly due to their ability to advance industrial application of scientific knowledge. Much of the studies available in literature on this matter, however, have focused on USA's spin-offs, while still little attention has been paid to the European countries, and to Italy in particular. Thus, the aim of our research is twofold: first, to fill this gap in literature. Second, to propose, on the basis of the above mentioned literature review, a model of ex-ante evaluation of the spin-off companies' performance. Specifically, the research methodology followed was a combination of literature analysis and Delphi technique: we first extensively reviewed the extant literature on spin-off companies, then we proposed to a panel of expert the indicators that emerged from the literature as affecting the performance of academic spin-offs.
\end{abstract}

Keywords: academic spin-offs; university; performance; italy.

\footnotetext{
I Department of Industrial Engineering, University of Parma,V.le G.P. Usberti I8I/A, Parma (Italy), I43 I24. Phone: +39 052 I 905860. E-mail: barbara.bigliardi@unipr.it

2 Department of Economy and Technology, San Marino State University (RSM), Strada della Bandirola 33, San Marino, 47898. Phone: +39 0521 905887. E-mail: francesco.galati@unirsm.sm

${ }^{3}$ Department of Management and Engineering, University of Padova, Str.lla S.Nicola 3,Vicenza (Italy), I36 I00. Phone: +39 044499873 I.

E-mail: chiara.verbano@unipd.it
} 


\section{Introduction}

The generation and the application of new ideas, technologies and scientific knowledge are widely recognized as a fundamental prerequisite for the economic development, job creation and the formation of a competitive industrial structure (Gwyneth, 2006; Atasu et al., 2009). As a consequence, in today's competitive and globalised world one of the main ability of a manager is that to create new innovative products and companies, in order to promote the development and growth of his company. Both researchers and practitioners agree in stating that Universities and other public research organisations are some of the main sources of innovations (Tidd and Bessant, 20I I). In fact, as recognized by numerous studies (e.g., Bellini et al., 2000; Pleschak, 2003), the creation of a company from a research organisation is an excellent way to commercialise the results of public research, as well as a way to contribute to the economic and social welfare and regional development. The companies that result from a budding process from universities are referred to with the term of academic spin-off. Such companies contribute to technology transfer in two stages: first, they transfer technology from their parent organization to themselves, second, they transfer the technology to customers. In the last decade we assisted to a proliferation of such companies. The extant literature highlights a main reason for their growing economic importance: as the new "open innovation" model has been adopted by organizations, and especially from the bigger ones, it becomes of key importance collaboration with smaller companies with sophisticated scientific and knowledge basis, such as academic spin-offs that make available a multiple research environments and their multidisciplinarity. Academic spin-offs usually develop within high tech industries, such as biotechnology, medical technologies, information technologies, and their main activities are related to the transfer of technology and knowledge from University to industry. Scholars often highlighted the importance of the creation and dissemination of knowledge at universities as an important driving force for technological innovation and economic growth (Muller et al., 2004).

The high importance of universities for the development of spin-offs is widely recognized worldwide. Typical examples are Silicon Valley and the Boston Area in the US, as well as Cambridge and Oxford in the UK (Gibson and Smilor, 1991; Kassicieh et al., 1997). In Europe, the literature provides examples from Germany, a country known for outstanding technological inventions (Beibst and Lautenschlager, 2004; Spielkamp et al., 2004; Van Gelderen et al., 2004), thus demonstrating that there is still less attention in Europe and in particular in Italy. Specifically, even if the importance of an academic spin-off is widely recognized both in economic and in knowledge terms, to our knowledge there is still a few studies that proposed a general model for the ex-ante eval- uation of their performance. The extant literature, in fact, proposes different studies identifying the factors that may impact a spin-off performance, even if separately each other, and not included into a general model of evaluation. Moreover, much of these works are used for an ex-post evaluation, while to our knowledge an ex-ante evaluation model does not exist.

Thus, the aim of this paper is twofold: first to fill this gap and second to develop an ex-ante performance evaluation model for an academic spin-off. The paper is structured as follow: section 2 provides the main definitions and issue of academic spin-offs. Then, section 3 describes the research methodology adopted, that was a combination of literature review (step I) and Delphi technique (step 2). The results from these steps are proposed in section 4, together with the research framework obtained as final results from our study. Finally, section 5 concludes the paper discussing the results of our work, and indicating some possible development and the limits of our research.

\section{Academic Spin-offs}

Academic spin-offs, also called university spin-offs (USOs) are very special start-up companies, and are not fully comparable to other companies such as collegiate start-ups or technology-based start-ups in general. The extant literature has proposed over the years different definition of spin-off. Roberts and Malone (1996), for example, defined spin-offs as a mechanism in which governments seek to generate economic impact from their R\&D, by transferring technology from the R\&D function to a commercial organization. Similarly, Rogers and Takegami (200I) defined spin-offs as those companies based on the parent R\&D organizations, namely, the government R\&D laboratory, the University, the University research center, and private R\&D organizations. Nicolaou and Birley (2003) proposed a definition of spin-off that takes into account the human element of the spin-off itself, stating that a spin-off is "a company composed by individuals who were former employees of the parent organization, and where the technology and the academic inventors may spin off both from the institution, or where the technology spins out from the institution but the academic inventor is employed in the University, or finally where only the technology spins out while the academic inventor does not maintain relationships with new firm but may have equity". Shane (2004), defined an academic spin-off as "those high-tech companies whose core business is based on the commercial valorization of results of a scientific and technological research". More recently, Conti et al. (20II) defined spin-off companies as "those companies that germinate from a University, where a group of researchers compose the entrepreneurial unit aiming at the exploitation of skills and results from the research developed within the University". Regardless the

ISSN: 07 I8-2724. (http://www.jotmi.org)

Journal of Technology Management \& Innovation (c) Universidad Alberto Hurtado, Facultad de Economía y Negocios. 
definition adopted, it is possible to state that an academic spin-off involves the transfer of a core technology from an academic institution into a new company, and whose founders may include the inventor academic who may or may not be currently affiliated with the academic institution.

Academic spin-off are receving growing interest from both researchers and policy-makers, due to their ability in creating richness and in encouraging the development of scientifc knowledge, as also shown by the proliferation of studies on such a matter (e.g., Clarysse et al., 2002; Degroff and Roberts, 2003, 2004; Mustar et al., 2006; Mustar et al., 2008; Kennedy and Patton, 20II). Moreover, these companies are believed to have growth rates more rapid than companies operating in industries with lower technological intensity (Cooper et al., 1986), even if some limitations have to be recognised. Numerous research evaluated the impact of legislative changes and of universities' mechanisms on spinoffs' creation (e.g., Baldini, 20I0; Colombo et al., 20I0; Fini et al., 2010; Lockett et al., 2005; Moray and Clarysse, 2005; Nosella and Grimaldi, 2009). Similarly, researchers are recently paying more and more attention on University patents (Baldini, 2009; Baldini et al., 2006; Breschi et al., 2008; Lissoni et al., 2008). Some empirical studies proposed for spin-offs companies a life cycle process similar to that of non spin-offs ones. Gartner (1985) and more recently Helm and Mauroner (2007), for example, identified three steps in their life cycle, namely: pre spin-off phase, spin-off establishment, and post spin-off phase. Vohara et al. (2004) stressed that the phases that an academic spin-off go through are the following: research; opportunity framing; pre-organization; and re-orientation and sustainability. In the same year, Degroof and Roberts (2004) proposed three steps for the spin-off life cycle: origination; concept testing; and start-up support. Based on the study by Vohara et al. (2004), Vanaelst et al.
(2006) proposed the phases of research commercialization and opportunity screening, the organization-in-gestation phase, proof of viability of the newly established venture, and the maturity, as the four main steps spin-offs go through. In general, it is possible to state that a spin-off process deals, in the first stages, with searching for ideas, making decisions and creating a business plan, then it go through the market entry until the company establishment.

\section{Objectives and methodology}

The importance of USO and the scant literature available referred to the Italian landscape were the main motivations at the basis of our study. Thus, as previously mentioned, the objective of our study was twofold: first, to fill the gap in literature, second, to propose a model of ex-ante evaluation of the USOs' performance. To reach these objectives, a two-steps research strategy has been adopted. The following Figure I shows the methodology adopted to reach each objective, as well as the results obtained.

The first step of our research consisted in an extensive literature review. Three criteria were used to select and assess the potential studies. To be included in our review, a study had to:

I) deal with academic spin-offs and their performance. Thus, studies dedicated to other issues of academic spin-offs (i.e. not to their performance) were not retained;

2) be an article published between inclusively in a peer review journal. Thus, other publication forms (conference proceedings, books, newspapers articles, unpublished works, etc.) were not considered;
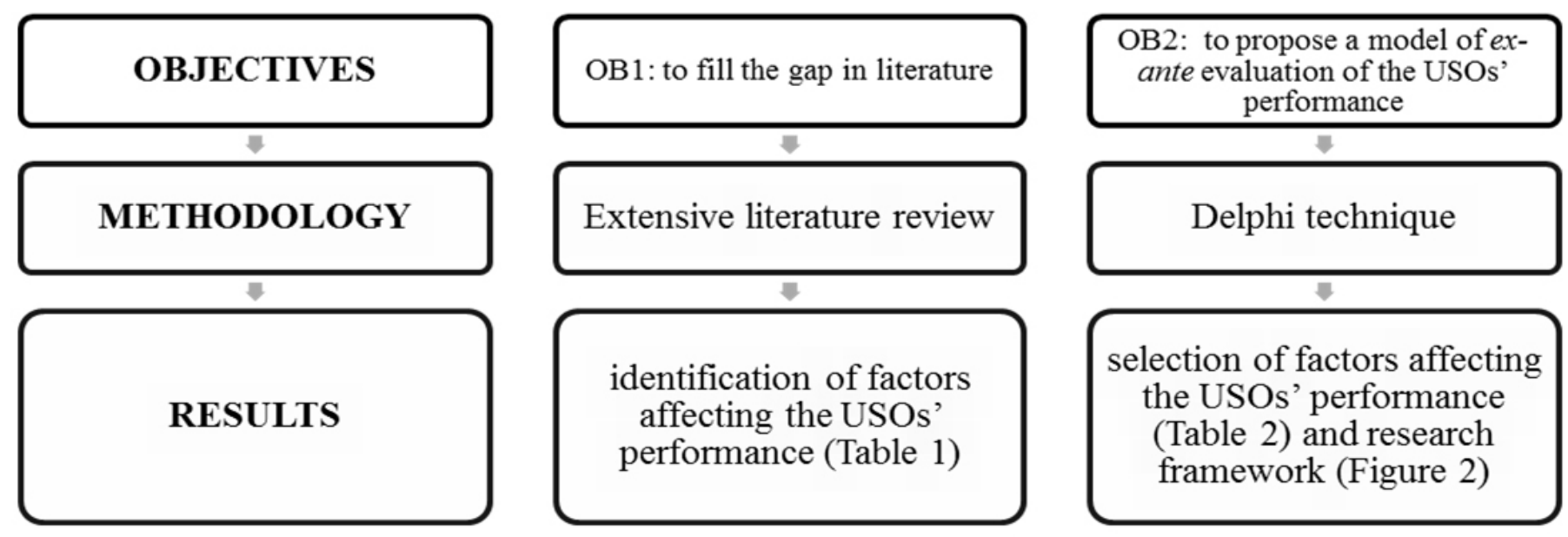

Figure I. Objectives and methodology.

ISSN: 07 I8-2724. (http://www.jotmi.org)

Journal of Technology Management \& Innovation (c) Universidad Alberto Hurtado, Facultad de Economía y Negocios. 
3) include an empirical study of academic spin-offs. Also case studies were included in the sample of papers to analyse. Moreover, we did not in any way restrict the data analysis method used by the authors-both descriptive statistics and econometric methods were included.

In order to do that, we first carried out a two-level computerized search by using as first "academic spin-offs" or "university spin-offs", and secondly "performance evaluation" or "performance assessment" as keywords in two different databases (ISIWeb of Knowledge and Scopus). The identified articles were then subjected to a double screening. First of all they have been sorted based on their title and summary and subsequently by analyzing the body of the remaining articles, and selecting only those focusing on ex-ante performance evaluation. After this double screening, all the selected articles were computer managed. Specifically, for the purposes of our study, we designed a Microsoft Excel database that contained each article's reference, the keywords, the year of publication and the journal where the paper is published, the nationality of the investigated USO, the sector(s) to which these firms belong, the statistical method used for data analysis as well as the conceptual ones. Finally, we obtained a sample of 21 papers to be included in the review, from which we derived the main factors as discussed in the following sections. The analysis of these articles has allowed us to identify the main factors affecting the performance of an USO.These factors will be detailed in the next section.

During the second step of the research, all the factors identified in step I have been proposed to a panel of expert set up to validate them, paying attention in balancing different skills of the panel members, mainly due to the multi-disciplinary nature of the problem examined. Thus, the panel was composed by 20 people, according the panel's size required by the Delphi technique, including:

- 4 academics belonging to two Italian Universities (namely, Parma University and Padua University), whose main research interest refer to technology transfer, with the aim to support the panel of experts during the decision making process;

- $\quad 10$ manager of as many academic spin-off belonging to an Italian University. These spin-offs operate within different industries (e.g., acoustics, electronics, logistics, automotive, etc.), thus allowing to cover a wide range of activities and representing a heterogeneous sample of spin-off companies;

- 6 people employed at the above mentioned spinoffs, both as managers or as R\&D managers.

The panel members operated with the Delphi technique (Linstone and Turoff, 1975), a structured process which allows experts to deal systematically with complex or ill- defined tasks, by means of controlled feedback and statistical response. On the basis of findings from the literature, reported in the following section, the 4 academics proposed the set of factors identified, structured into an appropriate questionnaire which was submitted to panel members. The questionnaire included two main section: the first one aimed at collecting the main descriptive data about the USO (area of activity, type of organization, number of employees, etc.) and the respondents (age and level of instruction, role in the USO, etc.), while the second one contained the list of factors identified on the basis of the literature review and a brief description. Hence, a two-round Delphi was carried out to refine the proposed factors. Specifically, in the first round, the panel members were asked to express their agreement against each factor, as well as to judge the suitability of their implementation in the case of their spin-off. Moreover, panellists were also asked to indicate the need for further specifications of factors, as well as the main strengths and weaknesses of each factor. The results of the first round of Delphi led to several modifications to the original list of factors (specifically, additional factors proposed by the panellists were incorporated while the non-relevant ones were eliminated). Hence, the original questionnaire was modified in order to include all the modifications to the factors proposed by the panellists during the first round of Delphi, and resubmitted to the panel members during the second round of Delphi. Again, panellists were asked to operate as during the first round. A general agreement was reached at the end of the second round. Then, a final roundtable discussion was carried out with all the panel members, aiming at confirming the agreements on the results of the second questionnaire.

\section{Results}

The extant literature proposes different studies identifying the factors that may impact a spin-off performance, even if separately each other, and not included into a general model of evaluation. All these studies move from the consideration that academic spin-offs involve unique challenges and success factors. For example, Kriegesmann (2000) highlighted the importance of the following 6 factors as impacting on spin-off performance: founder's need for autonomy, founder's need for leadership, founder's need for personal responsibility, founder's risk-taking responsibility, founder's preference for flat structures, formal contacts between parent and spin-off. Similarly, Egeln et al. (2003) identified these factors as positively impacting on the success of a spin-off activities: the founder's need for independence and autonomy, the founder's career orientation, the founder's motivation (in terms of independence in work, prospect of higher income, effective demand, career opportunity), professional training and education, formal contacts between parent and spinoff, job-order development. Both Beibst and Lautenschlager (2004) and Gassmann et al. (2003) in their study proposed

ISSN: 07 I8-2724. (http://www.jotmi.org)

Journal of Technology Management \& Innovation (c) Universidad Alberto Hurtado, Facultad de Economía y Negocios. 
Table I.The success factors identified in the literature review.

\begin{tabular}{|c|c|}
\hline Factors & References \\
\hline $\begin{array}{l}\text { 1. founder's need for autonomy } \\
\text { 2. founder's need for leadership } \\
\text { 3. founder's need for personal responsibility } \\
\text { 4. founder's risk-taking responsibility } \\
\text { 5. founder's preference for flat structure } \\
\text { 6. formal contacts between parent and spin-off }\end{array}$ & Kriegesmann (2000) \\
\hline $\begin{array}{l}\text { 1. founder's need for independence and autonomy } \\
\text { 2. founder's career orientation } \\
\text { 3. founder's motivation } \\
\text { 4. founder's professional training and education } \\
\text { 5. formal contacts between parent and spin-off } \\
\text { 6. job-order development }\end{array}$ & Egeln et al. (2003) \\
\hline $\begin{array}{l}\text { 1. founder's opportunity creation } \\
\text { 2. founder's career orientation }\end{array}$ & $\begin{array}{l}\text { Gassmann et al. (2003); Beibst and } \\
\text { Lautenschlager (2004) }\end{array}$ \\
\hline $\begin{array}{l}\text { 1. degree of innovativeness } \\
\text { 2. stage of development of the technology } \\
\text { 3. ability to patent or in general to protect the technology } \\
\text { 4. scope of the technology/product itself }\end{array}$ & Heirman and Clarysse (2004) \\
\hline $\begin{array}{l}\text { 1. financial involvement of the parent } \\
\text { 2. competent staff in technology transfer offices } \\
\text { 3. transparency and clarity of support policy } \\
\text { 4. access to qualified entrepreneurial skills }\end{array}$ & Smilor and Matthews (2004) \\
\hline $\begin{array}{l}\text { 1. mentoring } \\
\text { 2. professional training and education } \\
\text { 3. easy access to high qualified competences }\end{array}$ & Vohara et al. (2004) \\
\hline $\begin{array}{l}\text { 1. financial involvement of the University } \\
\text { 2. skills of the personnel employed within the technology transfer office } \\
\text { 3. relationships established with capital companies }\end{array}$ & Lockett et al. (2005) \\
\hline $\begin{array}{l}\text { 1. seed and venture capital availability } \\
\text { 2. regional infrastructure } \\
\text { 3. University intellectual property policy } \\
\text { 4. industry characteristics }\end{array}$ & O’Shea et al. (2005) \\
\hline
\end{tabular}




\begin{tabular}{|c|c|}
\hline $\begin{array}{l}\text { 1. incubation strategies } \\
\text { 2. access to relevant and qualified entrepreneurial knowledge }\end{array}$ & Clarysse et al. (2005) \\
\hline $\begin{array}{l}\text { 1. financial involvement of the parent } \\
\text { 2. formal contacts between parent and spin-off } \\
\text { 3. excellence and network integration of the parent }\end{array}$ & Scholten (2006) \\
\hline $\begin{array}{l}\text { 1. characteristics of the individual } \\
\text { 2. environment surrounding the new spin-off } \\
\text { 3. spin-off company itself }\end{array}$ & Phan and Siegel (2006) \\
\hline $\begin{array}{l}\text { 1. founder's unique history and experience } \\
\text { 2. human capital of the former scientist } \\
\text { 3. role played by the parent organizations } \\
\text { 4. location of the spin-off } \\
\text { 5. high degree of innovation and newness } \\
\text { 6. low technological maturity } \\
\text { 7. difficult judgment of the value of an innovative project } \\
\text { 8. easy recruiting of qualified staff members } \\
\text { 9. good capabilities and conditions for implementing innovations } \\
\text { 10. broad experience in Research and Development } \\
\text { 11. characteristics of the industrial sector the spin-off belongs to }\end{array}$ & Helm and Maurorer (2007) \\
\hline $\begin{array}{l}\text { 1. entrepreneurial origin } \\
\text { 2. technological knowledge }\end{array}$ & Clarysse et al. (2011) \\
\hline $\begin{array}{l}\text { 1. characteristics of the technology } \\
\text { 2. characteristics of the agents involved in the TT process as factors }\end{array}$ & Venturini et al. (2013) \\
\hline
\end{tabular}

the founder's opportunity creation and the founder's career orientation as the key factor impacting on spin-offs' performance. Smilor and Matthews (2004) showed that the support provided from Universities to spin-offs companies may increase the spin-off's success, thus proposing the following as important factors to be considered in determining their performance: financial involvement of the parent, competent staff in technology transfer offices, transparency and clarity of support policy, access to qualified entrepreneurial skills. According to Vohara et al. (2004), the success of a spin-off is influenced, in terms of support from the University and parent, by mentoring, professional training and education, and easy access to high qualified competences. Lockett et al. (2005) found that the number of spin-off companies increases with the R\&D expenditure of the University; the same Authors identified the financial involvement of the
University, the skills of the personnel employed within the technology transfer office, and the relationships established with capital companies as key factors in determining the success of a spin-off. In the same year, O'Shea et al. (2005) found evidence that the success of a spin-off company is positively related with the nature of University funding, the University quality, and the commercial capability of the University. The same Authors identified in their framework other factors, related to environmental issues, that determine the spin-off's success, namely: seed and venture capital availability, regional infrastructure, University intellectual property policy, and the industry characteristics. Clarysse et al. (2005), in their study on the one hand define the three main incubation strategies that can be adopted to create a spin-off, on the other hand stressed the importance of the access to relevant and qualified entrepreneurial knowledge in de-

ISSN: 07 I8-2724. (http://www.jotmi.org) 
termining a positive performance of the spin-off. Similarly, Scholten (2006) stressed the importance in determining the performance of an academic spin-off covered by the public research organisations in supporting the spin-off company. In particular, the Author identified the financial involvement of the parent, the formal contacts between parent and spin-off, and the excellence and network integration of the parent as the main factors. Phan and Siegel (2006) classified the factors affecting the success of academic spin-offs into three main classes, namely: the characteristics of the individual, the environment surrounding the new spin-off, and the created spin-off company itself. Helm and Maurorer (2007) proposed a list of specific and more detailed characteristics of academic spin-offs. Specifically, the Authors listed the following as key factors: founder's unique history and experience, specific human capital of the former scientist, specific role played by the parent organisation in the foundation of the enterprise and the business process, location of the spin-off, high degree of innovation and newness, low technological maturity, difficult judgment of the value of an innovative project, easy recruiting of qualified staff members, good capabilities and conditions for implementing innovations, broad experience in Research and Development, and characteristics of the industrial sector the spin-off belongs to. More recently, Clarysse et al. (20II) stressed the importance of technological resources in influencing the performance of an academic spin-off, namely: the degree of innovativeness, the stage of development of the technology, the ability to patent or in general to protect the technology, and the scope of the technology/product itself. This study confirmed the results from previous the study by Heirman and Clarysse (2004). Finally, Venturini et al. (2013), in their study on space TT, identified the characteristics of the technology and the characteristics of the agents involved in the TT process as factors (referred to with the term determinants by the same Authors) that facilitate the transfer process.

As for the performance of an academic spin-off, the review of the literature highlighted the existence of numerous studies dealing with this issue. For example, Egeln et al. (2003) showed that growth in sales, employment growth, and credit ranking are effective measures of the success of spin-offs. Shane and Stuart (2002) proposed the capacity to attract venture capital financing and the experiencing of initial public offerings as performance measures. Schmelter (2004) stated that the performance of a spin-off can be measured with the growth in sales and in the employment growth. Shane (2004) proposed to measure the number of job opportunity created to measure the performance of a spin-off company, while Ensley and Hmieleski (2005) adopted net cash flows and revenue growth as measures of performance. Helm and Maurorer (2007), defined the success of a spin-off

\begin{tabular}{|l|c|}
\hline \multicolumn{1}{|c|}{ Factors } & Average judgments \\
\hline 1. founder's need for autonomy & 4.3 \\
\hline 2. founder's risk-taking responsibility & 5.2 \\
\hline 3. formal contacts between parent and spin-off & 6.1 \\
\hline 4. founder's career orientation & 5.1 \\
\hline 5. founder's motivation & 6.4 \\
\hline 6. financial involvement of the parent & 6.3 \\
\hline 7. competent staff in technology transfer offices & 6.7 \\
\hline 8. access to qualified entrepreneurial skills & 6.8 \\
\hline 9. professional training and education & 5.2 \\
\hline 10. relationships established with capital companies & 5.9 \\
\hline 11. seed and venture capital availability & 5.9 \\
\hline 12. regional infrastructure & 5.5 \\
\hline 13. University intellectual property policy & 4.8 \\
\hline 14. the industry characteristics & 5.0 \\
\hline 15. location of the spin-off & 4.9 \\
\hline 16. degree of innovativeness & 5.3 \\
\hline 17. stage of development of the technology & 5.0 \\
\hline 18. ability to patent or in general to protect the technology & 5.2 \\
\hline
\end{tabular}

Table 2. The success factors (and their relative average judgment) identified after the two Delphi rounds.

ISSN: 07 I8-2724. (http://www.jotmi.org)

Journal of Technology Management \& Innovation (c) Universidad Alberto Hurtado, Facultad de Economía y Negocios. 
company as the achievement of technology transfer in addition to entrepreneurial and personal success. A summary of the factors that resulted from the systematic review of the literature are listed in Table I. The same table also reports the references that proposed the indicators.

During the second step of the research (namely, the Delphi technique), the factors listed in Table I were proposed, judged and selected from the panelists: the remaining factors, that is the factors judged as the main affecting the performance of an USO, are listed in Table 2. The same table also reports the average judgment (on the 7 point Likert scale proposed) assigned from the panelists to each factor. Only the factors with a judgment higher than 4 were retained and included in the following framework. As far as the performance is concerned, panellists agree in identifying the classical financial measures of performance as the most suitable in determining the performance of an academic spin-off.

Based on the results from the two steps, we derived the research framework that is depicted in Figure 2.

To obtain this framework, we grouped the factors resulted from the two Delphi rounds reported in Table I according to their main issues. Specifically, we identified four classification for the factors impacting on the performance of an academic spin-off, namely:
- University's characteristics: this group comprises those factors that refer to the characteristics and the level of involvement of the university, namely formal contacts between parent and spin-off, the financial involvement of the parent, competent staff in technology transfer offices, access to qualified entrepreneurial skills, professional training and education, relationships established with capital companies, and the university intellectual property policy.

- Founder's characteristics: founder's need for autonomy, founder's risk-taking responsibility, founder's career orientation and founder's motivation are the factors included in this group, representing the personal characteristics of the spin-off's founder;

- Environment's characteristics: this group includes the industry characteristics, the regional infrastructure, seed and venture capital availability, and the spin-off's location;

- Technological characteristics: factors included in this group are the degree of innovativeness, the stage of development of the technology, and the ability to patent or in general to protect the technology.

According to the judgements assigned to each factor by the panellists, and reported in previous Table 2, the four groups of characteristics that impact on the performance of an ac-

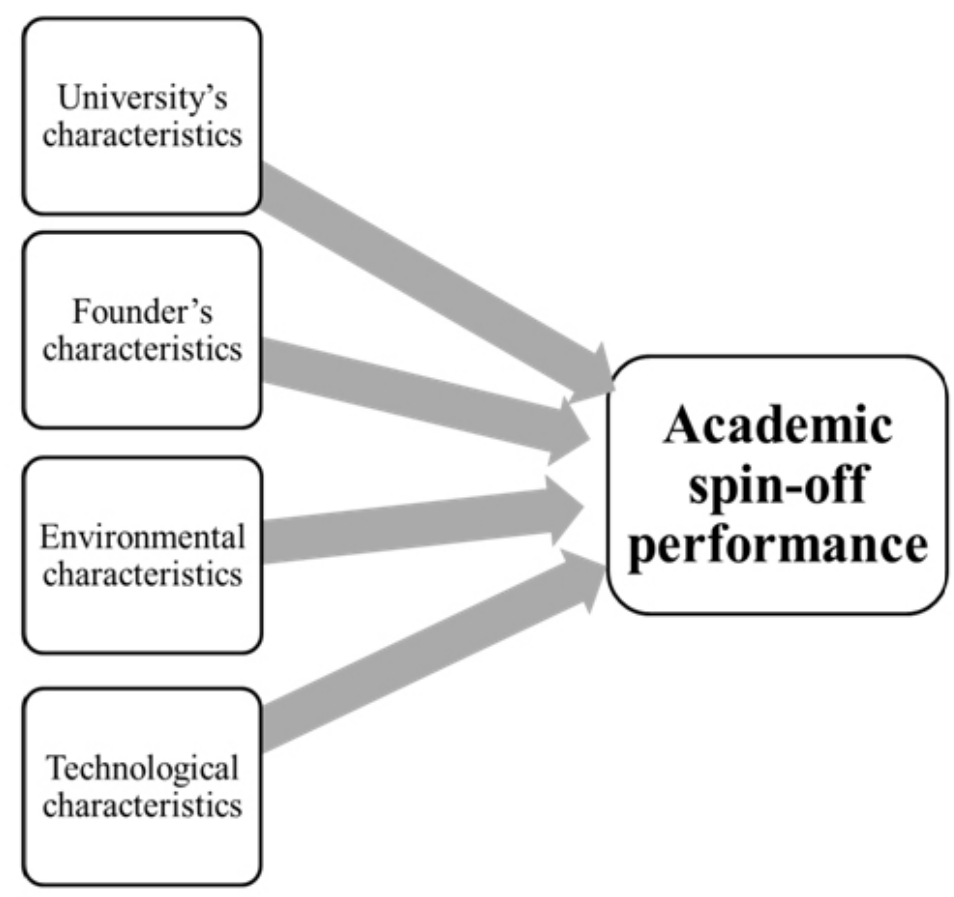

Figure 2. The research framework derived from the study.

ISSN: 07 I8-2724. (http://www.jotmi.org)

Journal of Technology Management \& Innovation (c) Universidad Alberto Hurtado, Facultad de Economía y Negocios. 
ademic spin-off may be ranked in order of importance as follows: University's characteristics (5.97), Environmental characteristics (5.33), Founder's characteristics (5.25) and Technological characteristics (5.17).

As for the performance measurement, the construct "Performance" is measured with the 4 financial factors previously identified, that is: growth in sales, employment growth, net cash flows, and revenue growth.

\section{Concluding remarks and future research}

Academic spin-offs companies are companies founded by an academic inventor aiming to exploit technological knowledge that originated within a University to develop products or services. These companies contribute to technology transfer in two stages: as first, they transfer technology from their parent organization to themselves and, secondly, they transfer the technology to customers. Such companies, in the last two decades, have received increasing attention from both researchers and practitioners, mainly due to their ability to advance industrial application of scientific knowledge. As a consequence, we assisted in the same period to a proliferation of such companies. The extant literature highlights a main reason for their growing economic importance: as the new "open innovation" model has been adopted by organizations, and especially from the bigger ones, it becomes of key importance collaboration with smaller companies with sophisticated scientific and knowledge basis, such as academic spin-offs that make available a multiple research environments and their multidisciplinarity. Notwithstanding the increasing interest towards academic spin-offs, much of the studies available in literature on this matter have focused on USA's spin-offs, while still little attention has been paid to the European countries, and to Italy in particular.

The objective of the research was twofold first, to fill the gap identified in literature, second, to propose, on the basis of the above mentioned literature review, a model of evaluation of the spin-off companies' performance. Thanks to the work of a panel composed by 20 people ( 4 academics and 16 members from 10 Italian spin-offs operating in different industries), a cause-effect theoretical framework among four types of characteristics antecedents and performance has been completed that fits to spin-off companies. To obtain such a framework, first we extensively review the extant literature in order to identify the success factors proposed in previous research, then the factors identified have been proposed to the panel of experts that has chosen a set of 18 factors. These 18 factors composed the final framework, and were grouped according to the characteristics they refer to, in three groups (namely, founder, university, environment and technology).
The framework proposed is, to our knowledge, one of the few frameworks proposed in the literature for the ex-ante measurement of a spin-offs performance. The next step of the research will consist in its validation within a sample of spin-offs, in order to test its suitability for the measurement of spin-offs' performance.

\section{References}

ATASU, A., Sarvary, M., Wassenhove, L., (2009). Remanufacturing as a Marketing Strategy. Management Science, 54(10), |73|-1747.

BALDINI, N. (2009). Implementing Bayh-Dole-like laws: Faculty problems and their impact on university patenting activity. Research Policy, 38, I2 I7-I 224.

BALDINI, N., (2010). University spin-offs and their environment. Technology Analysis and Strategic Management, 22(8).

BALDINI, N., Grimaldi, R., Sobrero, M. (2006). Institutional changes and the commercialization of academic knowledge: A study of Italian universities' patenting activities between 1965 and 2002. Research Policy, 35, 5I8-532.

BEIBST, G., Lautenschlager, A. (2004). Determinants of regional high-tech growth by university-based startups. In: Dowling, M, Schmude, J, Zu Knyphausen-Aufsess, D (eds) Advances in interdisciplinary European entrepreneurship research, Munster, pp 45-56.

BELLINI, N., Pammolli, F., Piccaluga, A. (2000). II ruolo dell'università nei processi di consituency-building per l'innovazione industriale e territoriale: riflessioni sull'esperienza italiana. Pisa, Siena and Lecce.

BRESCHI, S., Lissoni, F., Montobbio, F. (2008). University patenting and scientific productivity: a quantitative study of Italian academic inventors. European Management Review, 5, 91-109.

CLARYSSE B., Lockett A., Quince T., Van de Velde E., (2002), "Spinning off new ventures: a typology of facilitating services", Institute for the Promotion of Innovation by Science and Technology in Flanders, IWT-Observatory, Innovation, Science, Technology, n.4l.

CLARYSSE, B.,Wright, M., Lockett,A.,Van de Velde, E. (20I I). Entrepreneurial origin, technological knowledge and the growth of spin-off companies. Journal of Management Studies, 48(6), I 420-I 442. 
CLARYSSE, B.,Wright, M., Lockett,A.,Van de Velde, E.,Vohara, A. (2005). Spinning out new ventures: a typology of incubation strategies from European research institutions. Journal of Business Venturing, 20, 183-216.

COLOMBO, M., D'Adda, D., Piva, E. (2010). The contribution of university research to the growth of academic start-ups: an empirical analysis. Journal of Technology Transfer, 35, I-25.

CONTI G., Granieri M., Piccaluga A., (20I I), La gestione del trasferimento tecnologico. Strategie, Modelli e Strumenti. Springer, Milano.

COOPER A.C.,Willard G.E.,Woo C.Y., (1986), "Strategies of High Performance New Firms", Journal of Business Venturing, I (3), pp. 247-260.

DEGROOF J.J., Roberts E., (2004), "Overcoming weak entrepreneurial infrastructures for academic spin-off ventures", MIT Industrial Performance Center, Working Paper Series, MITIPC-04-005.

DEGROOF J.J., Roberts E., (2003), "Spinning-off new ventures from academic institutions in areas with weak entrepreneurial infrastructure: insights on the impact of spin-off processes on the growth-orientation of ventures", MIT Sloan School of Management, Working Paper, 43 I I-03.

EGELN, J., Gottschalk, S., Rammer, C., Spielkamp, A. (2003). Spinoff-Grundungen aus der offentlichen Forschung in Deutschland, Baden-Baden.

ENSLEY, M. D., Hmieleski, K. M. (2005). A comparative study of new venture top management team composition, dynamics and performance between university-based and independent start-ups. Research Policy, 34, I091-I 05.

FINI, R., Grimaldi, R., Marzocchi, G. L., Sobrero, M. (20I0). The Determinants of Corporate Entrepreneurial Intention within Small and Newly Established Firms. Entrepreneurship Theory and Practice, 36(2), 387-4I4.

GARTNER, W. B. (1985). A conceptual framework for describing the phenomenon of new venture creation. Academic Management Review, 10, 696-706.

GASSMANN, O., Escher, J. P., Luggen, M. (2003). Technologie verwertung durch Spin-off. Wissenschaftsmanagement Z Innov, 5, 24-30.
GIBSON, D.V., Smilor, R.W. (|99|). The role of the research university in creating and substaining the U.S. technopolis, In: Brett AM, Gibson DV, Smilor RW (eds) University spin-off companies: economic development, faculty entrepreneurs, and technology transfer. Rowman \& Littlefield, Savage, pp. 3I-70.

GWYNETH, D. (2006). Launching your Product: Seven Marketing Musts. Marketing Profs.

HEIRMAN, A., Clarysse, B. (2004). How and why do research-based start-ups differ at founding? A resource-based configurational perspective. Journal of Technology Transfer, 29(3-4), 247-268.

HELM, R., Mauroner, O. (2007). Success of research-based spin-offs, State-of-the-art and guidelines for further research. Review Managerial Science, I (2), 237-270.

KASSICIEH, S. K., Radosevich, H. R., Banbury, C. M. (1997). Using attitudinal, situational, and personal characteristics variables to predict future entrepreneurs from national laboratory inventor. IEE Transactions on Engineering Management, 44(3), 248-257.

KENNEY M., Patton D., (20II), "Research Does inventor ownership encourage university research derived entrepreneurship? A six university comparison", Research Policy, 40(8), pp. II00-III 2.

KRIEGESMANN, B. (2000). Unternehmensgründungen aus derWissenschaft. Eine empirische Analyse zu Stand. Entwicklungen und institutionellen Rahmenbedingungen in außeruniversitaren Forschungseinrichtungen. Z Betriebswirtschaft, 70(4), 397-4I4.

LINSTONE, H. A., Turoff, M. (1975). The Delphi Method, Techniques and Applications. Addison-Wesley, London.

LISSONI, F., Llerena, P., McKelvey, M., Sanditov, B. (2008).Academic patenting in Europe: new evidence from the KEINS database. Research Evaluation, 17, 87-102.

LOCKETT, A., Siegel, D.,Wright, M., Ensley, M. D. (2005). The creation of spin-off firms at public research institutions: managerial and policy implications. Research Policy, 34, 98I993.

MORAY, N., Clarysse, B. (2005). Institutional change and resource endowments to science-based entrepreneurial firms. Research Policy, 34, I0 I0-1027.

MULLER, C., Fujiwara, T., Herstatt, C. (2004). Sources of bioentrepreneurship: the cases of Germany and Japan. Journal of Small Business Management, 42(I), 93-10I.

ISSN: 07I 8-2724. (http://www.jotmi.org) 
MUSTAR P.,Wright M., Clarysse B., (2008), “University spinoff firms: Lessons from ten years of experience in Europe", Science and Public Policy, 35, pp. 67-80.

MUSTAR, P., Renault, M., Colombo, M. G., Piva, E., Fontes, M., Lockett, A., Wright, M., Clarysse, B., Moray, N. (2006). Conceptualising the heterogeneity of research-based spin-offs: a multidimensional taxonomy. Research Policy, 35, 289-308.

NICOLAOU, N., Birley, S. (2003). Academic networks in a trichotomous categorisation of university spinouts. Journal of Business Venturing, I8(3), 333-359.

NOSELLA, A., Grimaldi, R. (2009). University level mechanisms supporting the creation of new companies: an analysis of Italian academic spin-offs. Technology Analysis and Strategic Management, 2I, 679-698.

O'SHEA, R., Allen, T., Chevalier, A. (2005). Entrepreneurial orientation, technology transfer, and spin-off performance of U.S. Universities. Reserch Policy, 34(7), 994- 1009.

PHAN, P. H., Siegel, D. S. (2006). The effectiveness of university technology transfer. Foundation and Trends in Entrepreneurship, 2(2), 77-I 44.

PLESCHAK, F. (2003). Entwicklungstendenzen des Technologie transfers und Anforderungen an seine Ausgestaltung. In: Pleschak F. (ed) Technologie transfer,Anforderungen und Entwicklungstendenzen, Karlsruhe, pp I-I6.

ROBERTS, E., Malone, D. E. (1996). Policies and structures for spinning off new companies from research and development organizations. R\&D Management, 26, 17-48.

ROGERS, E. M., Takegami, S., Yin, J. (200I). Lessons learned about technology transfer. Technovation, 2I (4), 253-26I.

SCHMELTER, A., (2004). Entwicklungsverlaufe forschungsnaher Unternehmensgrundungen und deren Determinanten. Die Betriebswirtschaft, 64 (4), 47 I-486.

SCHOLTEN,V.E. (2006). The early growth of academic spinoffs. Ph.D.Thesis, Wageningen University.

SHANE S. (2004), Academic entrepreneurship: University spin-offs and wealth creation, Cheltenham, UK: Edward Elgar.

SHANE, S., Stuart, T. (2002). Organizational endowments and the performance of university start-ups. Managment Science, 48(I), I54-I70.
SMILOR, R. W., Matthews, J. (2004). University venturing: technology transfer and commercialisation in higher education. International Journal Technological Transfer Commercial, 3(I), I I - I 28.

SPIELKAMP, A., Egeln, J., Gottschalk, S., Rammer, C. (2004). Spin-offs in Germany-conceptual considerations and empirical evidence. In: Dowling M, Schmude J, Zu Knyphausen-Aufsess, D (eds) Advances in interdisciplinary European entrepreneurship research, Munster, pp. 153-181.

TIDD, J., Bessant, J. (20I I). Managing Innovation: Integrating Technological, Market and Organisational Change (4th ed.). Wiley: Chichester.

VAN GELDEREN, M., Brand, M., Van Praag, M., Ombach, M., Bodewes, W., (2004), "Some advances in the explanation of entrepreneurial intentions", In: Dowling M, Schmude J, Zu Knyphausen-Aufsess $D$ (eds) Advances in interdisciplinary European entrepreneurship research, Munster, pp. 27-44.

VANAELST, I., Clarysse, B., Wright, M., Lockett, A., Moray, N., S'Jegers, R. (2006). Entrepreneurial team development in academic spinouts: An examination of team heterogeneity. Entrepreneurship Theory and Practice, 30(2), 249-27I.

VENTURINI, K., Verbano, C., Matzumoto, M. (20I3). Space technology transfer: spin-off cases from Japan. Space Policy, 29, 49-57.

VOHARA, A., Wright, M., Lockett, A. (2004). Critical junctures in the development of university high-tech spinout companies. Research Policy, 33, I47-175. 